\title{
Body mass distributions along successional gradients in epigeic carabid beetle fauna (Coleoptera: Carabidae)
}

\author{
ARMIN SCHREINER ${ }^{1}$ \\ ADAM KWIATKOWSKI ${ }^{2}$ \\ JAN SZYSZKO ${ }^{3}$ \\ AXEL SCHWERK ${ }^{3}$ \\ ${ }^{1}$ Am Schultenbrink 50, 45549 Sprockhövel, Germany \\ ${ }^{2}$ Horodnianka 1, 16-020 Czarna Białostocka, Poland \\ ${ }^{3}$ Laboratory of Evaluation and Assessment of Natural \\ Resources, Warsaw University of Life Sciences - \\ SGGW, Nowoursynowska Street 166 \\ 02-787 Warsaw, Poland \\ Correspondence: \\ Axel Schwerk \\ E-mail:aschwerk@yahoo.de

\section{Nonstandard abbreviations} \\ MIB: Mean individual biomass of Carabidae
}

Key words: MIB, succession, forest, post-industrial area, bioindication
Received December 14, 2015.

Revised May 11, 2016

Accepted May 16, 2016.

\begin{abstract}
Background and purpose: Body mass distributions may be related to the stage of succession of a habitat and provide with information for assessing successional processes. Therefore, body mass distributions of carabid assemblages were studied in three research areas, which were post-industrial areas near the city of Betchatów (Central Poland) planted with different tree and shrub species, moist and wet forest stands in the Puszcza Knyszyniska forest (Northeastern Poland), and beech stands in the Rubr valley (Western Germany) in order to analyze the changes in body mass distributions within single assemblages along successional gradients.
\end{abstract}

Materials and Methods: For each carabid assemblage, the mean individual biomass $(M I B)$ as well as MIB standard deviation (SD) and coeffcient of variation $(C V)$ were calculated. $S D$ and $C V$ were plotted against the age of study sites and MIB values, respectively. Analyses of Covariance (ANCOVA) were carried out with $S D$ and $C V$ as dependent variables and the age of study sites and MIB as covariates.

Results: SD was low at young stages of succession, but increased rapidly and plateaued at advanced stages in beech but not in wet forest stands. Accordingly, CV was low at very young stages of succession, showing a rapid increase and subsequent decrease in the beech stands, whereas in the wet stands it stayed on a constant level. ANCOVA revealed significant differences in $S D$ and $C V$ between the research areas and significant changes with age or $M I B$, but, with the exception of $C V$ as dependent variable and $M I B$ as covariate, interactions were also significant.

Conclusions: The results of the study suggest that data on body mass distributions within single carabid assemblages may be useful in the assessment and comparison of successional stages and processes between different habitat types.

\section{INTRODUCTION}

The biomass and body size of organisms have been linked to several 1 ecological factors (e.g. 1, 2, 3, 4, 5). Lindenmayer et al. (6) classified species which provide much of the biomass or number of species in an area as being potential indicators of environmental conditions. Accordingly, Koivula (7) called such species "dominance indicators". In this context, he also discussed the indicatory potential of changes in carabid body size or biomass linked to ecological processes. 
Carabid beetles have been used in ecological research in different habitat types such as primeval forests, mountain ranges, or brownfields (e.g. 8, 9, 10). In some of these studies, the body size of the beetles or their body mass, respectively, has been analyzed, indicating that either small carabids of low body mass or large carabids of high body mass may dominate in an assemblage, depending on the environmental conditions given. It has been shown that average body size in carabid assemblages decreased with increasing disturbance (e.g. 11). Cárdenas \& Hidalgo (12) used mean body mass differences in order to assess environmental recovery processes. Several studies deal with the mean individual biomass of Carabidae (MIB) as indicator of the stage of succession of a habitat (e.g. 13, 14, 15). MIB is based on the observation that in carabid assemblages smaller open-habitat species are replaced by larger forest species with ongoing succession of a habitat $(13,16)$. Yet, reanalyzing size trends in carabids at an abandoned fertilizer factory in Germany (17), Lövei \& Magura (18) showed that, dividing carabid beetles into different functional groups with respect to their foraging strategy, the size trends indicate group-specific differences.

However, the same MIB value may result from different body mass distributions within a carabid assemblage. On the one hand, the species and individuals might cover a wide range of body masses and therefore the MIB variation may be high, whereas, on the other hand, their body masses might be fairly homogenous, resulting in a low variation of MIB. Just as assumed for the MIB value itself, the underlying body mass distributions may be related to the habitat or certain habitat characteristics. Since MIB is related to the stage of succession the body mass distribution may be, too, and may provide with additional information for assessing successional processes. Hence, the aim of this work was to study potential changes in body mass distribution patterns of epigeic carabid beetles in relation to successional stages.

In order to characterize the body mass distribution patterns we calculated the standard deviation (SD) for our samples. Since the standard deviation to a certain extend depends on the mean value we also calculated the coefficient of variation (CV), i.e. SD divided by mean.

For characterization of the successional stage we also used two measures. Generally, we may assume that succession progresses with increasing age of a study site after renaturation or afforestation. However, depending on environmental conditions, succession may proceed faster or slower. For example, in many post-industrial areas (primary) succession is delayed $(19,20,21)$. Therefore, we used the age of study sites along with the MIB as an indicator of the stage of succession.

We analyzed study sites of different age in selected research areas, which were post-industrial areas located close to the city of Bełchatów (Central Poland) (22), wet forests in the Puszcza Knyszyńska (Northeastern Poland) (23), and beech forests in the Ruhr valley (Western Germany) (24). We wanted to study the changes of SD and CV along the successional gradient as measured by the age and particularly MIB of study sites, and their potential differences between the research areas. We also wanted to test whether or not any interaction between the research area and age or MIB exists with respect to SD or CV.

\section{METHODS}

\section{Research areas and field methods}

A detailed description of the study sites in the three research areas is provided in Table 1.

From the industrial activity at Bełchatów of brown coal mining and electricity production two heaps of waste material originated: A heap of ashes produced by the power station, on which three sites of different age since renaturation with tree and shrub species were sampled, and a heap of stony material produced during the mining process, on which four sites (pine stands) of different age were sampled from 2004 to 2011. On each site, 3 pitfall traps were installed. Since in some samples the number of individuals was very low, data of each two consecutive years were pooled for each study site, resulting in 28 samples with an age-of-site range of 3-27 years (Appendix 1).

Puszcza Knyszyńska is one of the biggest forest complexes in Poland with an overall area of about 114,000 ha. Here, 24 study sites in wet and humid forest habitats were selected. The sampling period was 2006-2008 with 3 pitfall traps installed on each site. Since at individual study sites the traps were temporarily flooded in some years due to strong fluctuations of the water level the data of all 3 years of study were pooled for each study site, resulting in 24 samples with an age-of-site range of 3-127 years, with age defined as the age of the respective study site in 2007 (Appendix 1).

In the Ruhr valley in Western Germany, 14 sites in afforested beech forests were selected for inventory. With 3 pitfall traps on each study site, sampling was carried out in the years 2009 and 2010, resulting in 28 samples (ageof-site range from 1 to 166 years, Appendix 1).

Pitfall traps were containers topped with a funnel (upper diameter of about $10 \mathrm{~cm}$ ) set flush with the soil surface. A roof was suspended a few $\mathrm{cm}$ above the funnel and ethylene glycol was used as a killing agent and preservative. Sampling times covered mid/late-April (beginning of May in 2010) to $\mathrm{mid} /$ late-October at Bełchatów, mid-May to late-September in Puszcza Knyszyńska, and mid-April to mid-November (2009) and early-April to mid-October (2010) in the Ruhr valley. Despite differences in exposure of the traps the main peaks of carabid activity were covered by the sampling periods in each research area.

Determination of collected individuals was carried out according to the nomenclature of Freude et al. (25). 
Tab. 1: Description of the study sites in the research areas Betchatów (BE), Puszcza Knyszynska (PK), and Ruhr valley (RV).

\section{Study Description}

site

BE1 Plantation on ash heap, dominated by robinia (Robinia pseudoacacia), sea buckthorn (Hippophäe rhamnoides), and Siberian peashrub (Caragana arborescens), about 8 years old in 2004

BE2 Plantation on ash heap, dominated by birch (Betula sp.) and pine (Pinus sylvestris), about 10 years old in 2004

BE3 Plantation on ash heap, dominated by robinia (Robinia pseudoacacia) and sea buckthorn (Hippophäe rhamnoides), about 12 years old in 2004

BE4 Pine (Pinus sylvestris) plantation on spoil heap, 3 years old in 2004

BE5 Pine (Pinus sylvestris) plantation on spoil heap, 10 years old in 2004

BE6 Pine (Pinus sylvestris) plantation on spoil heap, 14 years old in 2004

BE7 Pine (Pinus sylvestris) plantation on spoil heap, 21 years old in 2004

PK1 Black alder (Alnus glutinosa) stand with spruce (Picea abies), 3 years old in 2007

PK2 Black alder (Alnus glutinosa) stand with spruce (Picea abies), birch (Betula pubescens), and oak (Quercus robur), 3 years old in 2007

PK3 Black alder (Alnus glutinosa) stand with spruce (Picea abies) and oak (Quercus robur), 3 years old in 2007

PK4 Black alder (Alnus glutinosa) stand with spruce (Picea abies), sporadically oak (Quercus robur), 4 years old in 2007

PK5 Black alder (Alnus glutinosa) stand with spruce (Picea abies) and ash (Fraxinus excelsior), 7 years old in 2007

PK6 Black alder (Alnus glutinosa) and spruce (Picea abies) stand, with ash (Fraxinus excelsior) and oak (Quercus robur), 8 years old in 2007

PK7 Oak (Quercus robur) and black alder (Alnus glutinosa) stand with spruce (Picea abies) and ash (Fraxinus excelsior), 13 years old in 2007

PK8 Mixed stand with black alder (Alnus glutinosa), oak (Quercus robur), hornbeam (Carpinus betulus), and birch (Betula pubescens), sporadically pine (Pinus sylvestris), 22 years old in 2007

PK9 Black alder (Alnus glutinosa) stand with birch (Betula pubescens), 26 years old in 2007

PK10 Black alder (Alnus glutinosa) stand with birch (Betula pubescens), ash (Fraxinus excelsior), and spruce (Picea abies), 28 years old in 2007

PK11 Black alder (Alnus glutinosa) and birch (Betula pubescens) stand with spruce (Picea abies) and ash (Fraxinus excelsior), 29 years old in 2007

PK12 Black alder (Alnus glutinosa) stand with birch (Betula pubescens), 46 years old in 2007

PK13 Birch (Betula pubescens) and black alder (Alnus glutinosa) stand with spruce (Picea abies), 46 years old in 2007

PK14 Spruce (Picea abies) stand with pine (Pinus sylvestris) and black alder (Alnus glutinosa), sporadically oak (Quercus robur) and birch (Betula pubescens), 68 years old in 2007
PK15 Black alder (Alnus glutinosa) stand with spruce (Picea abies) and birch (Betula pubescens), 73 years old in 2007

PK16 Black alder (Alnus glutinosa) stand with spruce (Picea abies), sporadically birch (Betula pubescens) and ash (Fraxinus excelsior), 78 years old in 2007

PK17 Spruce (Picea abies) and black alder (Alnus glutinosa) stand with birch (Betula pubescens) and ash (Fraxinus excelsior), sporadically aspen (Populus tremula) and lime (Tilia cordata), 81 years old in 2007

PK18 Black alder (Alnus glutinosa) stand with spruce (Picea abies) and birch (Betula pubescens), sporadically pine (Pinus sylvestris), 83 years old in 2007

PK19 Spruce (Picea abies) stand with birch (Betula pubescens), pine (Pinus sylvestris), and aspen (Populus tremula), 91 years old in 2007

PK20 Black alder (Alnus glutinosa) and spruce (Picea abies) stand with birch (Betula pubescens) and ash (Fraxinus excelsior), 93 years old in 2007

PK21 Spruce (Picea abies) stand with black alder (Alnus glutinosa), sporadically pine (Pinus sylvestris), 93 years old in 2007

PK22 Spruce (Picea abies) stand with pine (Pinus sylvestris) and black alder (Alnus glutinosa), sporadically birch (Betula pubescens) and ash (Fraxinus excelsior), 101 years old in 2007

PK23 Spruce (Picea abies) stand with black alder (Alnus glutinosa) and birch (Betula pubescens), sporadicallv aspen (Populus tremula) and ash (Fraxinus excelsior), 103 years old in 2007

PK24 Black alder (Alnus glutinosa) stand with few spruce (Picea abies), 127 years old in 2007

RV1 Beech (Fagus sylvatica) stand with larch (Larix sp.) and cherry (Prunus sp.), 1 year old in 2009

RV2 Beech (Fagus sylvatica) stand with $5 \%$ cherry (Prunus sp.), 1 year old in 2009

RV3 Beech (Fagus sylvatica) stand, 3 years old in 2009

RV4 Beech (Fagus sylvatica) stand, 4 years old in 2009

RV5 Beech (Fagus sylvatica) stand, 13 years old in 2009

RV6 Beech (Fagus sylvatica) stand, 20 years old in 2009

RV7 Beech (Fagus sylvatica) stand with $10 \%$ larch (Larix sp.), 26 years old in 2009

RV8 Beech (Fagus sylvatica) stand with larch (Larix sp.) and cherry (Prunus sp.), 28 year old in 2009

RV9 Beech (Fagus sylvatica) stand with $10 \%$ larch (Larix sp.), 52 years old in 2009

RV10 Beech (Fagus sylvatica) stand with $10 \%$ oak (Quercus sp.), 26 years old in 2009

RV11 Beech (Fagus sylvatica) stand, 146 years old with 10 -year-old byplants in 2009

RV12 Beech (Fagus sylvatica) stand, 146 years old in 2009

RV13 Beech (Fagus sylvatica) stand with $10 \%$ oak (Quercus sp.), 152 years old in 2009

RV14 Beech (Fagus sylvatica) stand, 165 years old in 2009 
Tab. 2: ANCOVA results of SD and CV. Area - research area, age - age of study sites, $M I B$ - mean individual biomass of Carabidae.

\begin{tabular}{|ccccc|}
\hline Dep. var. & Factor & df & F & p \\
\hline SD & Area & 2 & 59.672 & 0.000 \\
& Age & 1 & 14.604 & 0.001 \\
& Area ${ }^{*}$ Age & 2 & 10.798 & 0.000 \\
SD & Area & 2 & 36.188 & 0.000 \\
& MIB & 1 & 79.630 & 0.000 \\
& Area ${ }^{*}$ MIB & 2 & 36.214 & 0.000 \\
CV & Area & 2 & 18.587 & 0.000 \\
& Age & 1 & 5.277 & 0.031 \\
& Area ${ }^{*}$ Age & 2 & 5.731 & 0.008 \\
CV & Area & 2 & 30.571 & 0.000 \\
& MIB & 1 & 30.880 & 0.000 \\
\hline
\end{tabular}

a
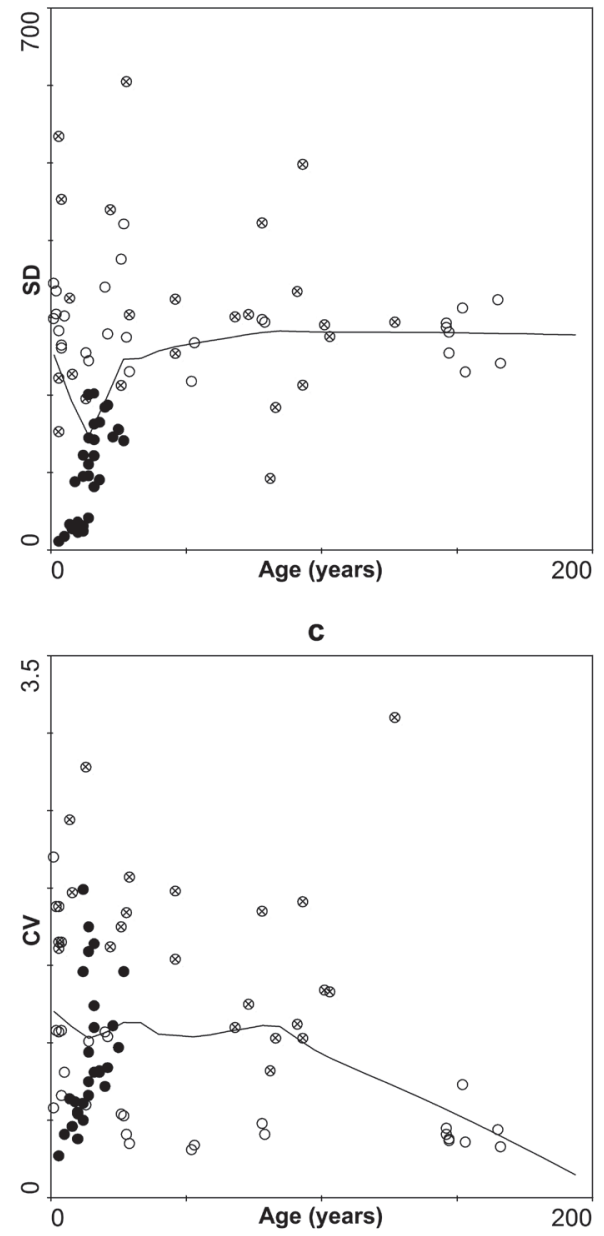

\section{Statistical methods}

For each sample, the mean individual biomass (MIB), standard deviation (SD), and coefficient of variation (CV) were calculated.

MIB values were calculated by dividing the biomass of all carabids in a sample by the number of specimens caught. Biomass values for the species recorded were those cited by Szyszko (13) or obtained using the equation by Szyszko (26) which describes the relationship between the body length of a single carabid individual $(x)$ and its biomass $(y)$ :

$$
\ln y=-8.92804283+2.55549621 \times \ln x
$$

$\mathrm{SD}$ and $\mathrm{CV}$ were plotted against the age of study sites and MIB, respectively. Robust fitted locally weighted scatterplot smoothing (LOESS) models were applied in order to generate response curves to the data sets, using b

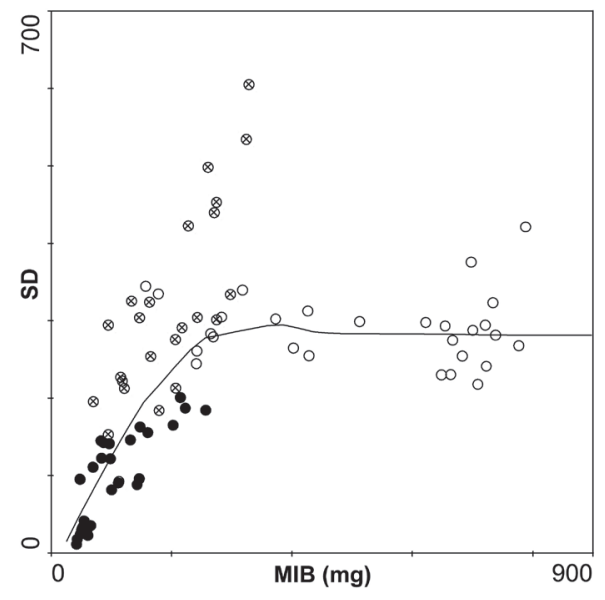

d

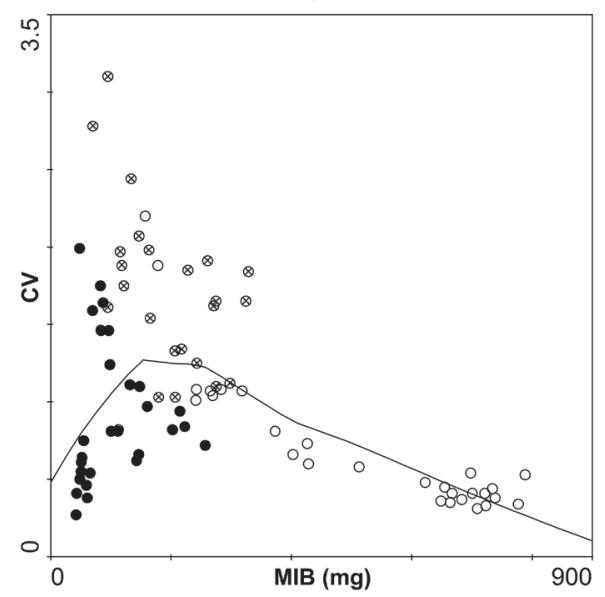

Fig. 1: SD and CV for all study sites (๑, Betchatów; $\otimes$, Puszcza Knyszyńska; $\bigcirc$, Ruhr valley) plotted against age of study sites and MIB, respectively, with LOESS curves drawn for (a) SD and age of study sites (LOESS: residual standard error $=102.3536$, multiple R-squared $=0.296$ ), (b) SD and MIB (LOESS: residual standard error $=67.2909$, multiple R-squared $=0.604)$, (c) CV and age of study sites (LOESS: residual standard error $=0.6149$, multiple R-squared $=0.057)$, and $(d) C V$ and MIB (LOESS: residual standard error $=0.4806$, multiple R-squared $=0.337)$. 
CanoDraw for Windows 4.14 (27). We used a local linear model and a span value of 0.67 . Predictors were not conditionally parametric and we normalized the scale for two predictors.

In order to study the potential influence of the research area, repeated-measures analyses of covariance (ANCOVA) were carried out using IBM SPSS Statistics v. 22, with $S D$ and $C V$ as dependent variables and second-order effects of age and MIB as covariates. The initial models included interactions with the covariate, but all non-significant interactions were removed from the final model.

\section{RESULTS}

Altogether, 22,786 carabid individuals were collected. In the research area Bełchatów the number of individuals amounted to 3,550, with individuals per sample ranging from 29 to 621. In the research area Puszcza Knyszyńska 8,903 individuals were collected (61 to 1,353 individuals per sample) while in the Ruhr valley the number of individuals was 10,333 (42 to 866 individuals per sample; Appendix 1).

When SD is plotted against the age of study sites (Fig. 1a) and MIB (Fig. 1b), respectively, for the study sites at Bełchatów an increase is visible in both cases. For the study sites of Puszcza Knyszyńska SD values are generally high and show no trend when plotted against the age of study sites, but increase when plotted against MIB. The study sites of the Ruhr valley show no trend in both cases. For this research area $S D$ values are also high, but variation in SD values is low compared to the values elaborated for Puszcza Knyszyńska. Taking into account all three research areas, SD plotted against the age of study sites results in a LOESS curve which drops sharply until about 15 years are reached on the age axis, followed by a steep increase until an age of about 25 years is reached. From then on, the curve shows almost horizontal progression. However, when plotting SD against MIB, the LOESS curve shows a steep increase for low MIB values while it flattens and continues horizontally from MIB values of about $300 \mathrm{mg}$.

CV plotted against age (Fig. 1c) shows an increase with very high values at an age of about 15 years for the study sites at Bełchatów. When plotted against MIB (Fig. 1d), for this research area CV shows a clear increase with MIB values up to about $100 \mathrm{mg}$, but with higher values for MIB a slight decrease is visible. For the study sites in Puszcza Knyszynska the CV values are in general very high. Plotted against both the age of study sites and MIB they describe an arch which reaches the lowest values at an age of about 80 years and a MIB of about $260 \mathrm{mg}$, respectively. For the study sites in the Ruhr valley the CV values show high variation for young study sites and low variation for older ones. When plotted against MIB, the values drop steadily. Taking into account all three re- search areas, CV plotted against the age of study sites leads to horizontal progression of the LOESS curve until an age of about 80 years is reached, whereas, when $\mathrm{CV}$ is plotted against MIB, an increase until about $150 \mathrm{mg}$ are reached on the MIB axis, followed by a slight decrease which becomes more pronounced from about $250 \mathrm{mg}$, can be discerned.

With age of study sites as covariate, ANCOVA revealed significant differences of both $S D$ and $C V$ between the research areas. SD and CV changed significantly with increasing age of sites. Yet, for both SD and CV, a significant interaction between the research area and age of sites was detected (Tab. 2). When using MIB as covariate, significant differences of both $\mathrm{SD}$ and $\mathrm{CV}$ were again detected between the research areas. Both changed significantly with increasing MIB. However, whereas a significant interaction between the research area and MIB existed with respect to $S D$, no significant interaction was revealed with respect to $C V$ (Tab. 2).

\section{DISCuSSION}

To our knowledge, changes in SD and CV of body mass distributions in carabid assemblages have not been studied in detail up to now. Studying differences between the mean and median body length in populations of Carabus arvensis, Carabus violaceus, and Pterostichus niger, Garbalińska \& Skłodowski (28) concluded that particular species may show different patterns of body size adaptation to hurricane-induced habitat changes. Schreiner \& Schwerk (29) analyzed possible changes in SD of elytra length of the species Carabus violaceus and Carabus problematicus in the beech stands of the Ruhr valley, but neither for males nor for females a significant correlation between SD and age of stands could be detected. Having analyzed the current data with LOESS models and ANCOVA we can indeed state that body mass distributions change along successional gradients and that differences in the changes between the research areas exist. However, with the exception of $\mathrm{CV}$ as dependent variable and MIB as covariate, there were significant interactions between research area and succession.

Data on the age of study sites as an indicator of succession show a much higher scatter than data on MIB, which is underscored by lower multiple R-squares for both $\mathrm{SD}$ and CV. Particularly high variability can be observed in Puszcza Knyszyńska and young study sites in the Ruhr valley. In Puszcza Knyszyńska, this may be due to a general lack of succession processes as already indicated by the fact that MIB does not correlate with the age of study sites (23). The strong habitat dynamics may be caused by fluctuating water conditions. Soil conditions and forestry methods might also play a role (30). In the Ruhr valley, our results may originate from a high variability of initial degradation levels. As a matter of fact, MIB values for 
young study sites in the research area Ruhr valley range from about $150 \mathrm{mg}$ up to more than $500 \mathrm{mg}$ (24).

It is evident that very low as well as very high MIB values are accompanied by comparatively low values for SD and CV. Therefore, SD and CV in a medium MIB range, i.e. at medium stages of succession, are particularly interesting. In this context, MIB values of about 150 $250 \mathrm{mg}$ seem to mark a decisive moment. This is when the SD curve flattens and the CV curve shows a maximum. This MIB range may represent a transition coenoses between carabid assemblages of open areas and those of advanced stages of succession. Here, changes in soil conditions may be an important factor since studies have shown that the distribution of woodland carabids may depend on the soil water holding capacity, soil trophic status, and soil acidity (31) or litter layer $(32,33)$. However, studying native beech forests and spruce plantations, Magura et al. (34) reported that also canopy closure has an influence on changes in carabid assemblages during forestry cycles.

Depending on the speed of succession, the described MIB range of a possible transition coenosis may be reached on individual study sites at a different age. Accordingly, the highest $\mathrm{CV}$ on the study sites at Bełchatów was observed for sites with an age of about 12-16 years, whereas in the Ruhr valley it was already reached on sites of a by far younger age. Interestingly, the CV peaks approximate the inflexion points of curves based on a logistic model of succession on the study sites in these areas $(35,24)$, i.e. the moment of maximum speed of succession.

Significant differences between the research areas were indicated by the results of ANCOVA. However, in three cases significant interaction was revealed and thus the response to the groups (research areas) should not be interpreted as an overall or average main effect (36). Accordingly, a significant difference between the research areas can be approved without reservation only for CV plotted against MIB. In all other cases we may merely assume a difference in response to the age of study sites or MIB between the research areas.

Management of successional stages is an important task with respect to biodiversity conservation, for instance on post-industrial areas (e.g. 14, 37) or in connection with construction projects (38). Diversification of successional stages is an important feature determining landscape structure (39). Habitat diversity, landscape structure, and land-use intensity have been proven to affect diversity patterns in different arthropod groups in temperate European agricultural landscapes (40). Hence, a variety of succession indicators is needed in order to manage sensitive habitats and landscapes effectively. Data on body mass distributions within single carabid assemblages may be useful in the assessment and comparison of successional stages and processes in different habitat types.

\section{Acknowledgements}

The authors thank Rikjan Vermeulen and an anonymous reviewer for their valuable comments on an earlier version of the manuscript and Karsten Hannig for confirming the determination of beetles. This paper is communication No. 474 of the Laboratory of Evaluation and Assessment of Natural Resources, Warsaw University of Life Sciences - SGGW.

\section{REFERENCES}

1. HESPENHEIDE H A 1973 Ecological inferences from morphological data. Ann Rev Ecol Syst 4: 213-229

2. CZECHOWSKI W 1980 Influence of the manner of managing park areas and their situation on the formation of the communities of carabid beetles (Coleoptera, Carabidae). Fragm Faun 25: 199-219

3. RINK U 1990 Struktur und Phänologie der Fauna von Laufkäfern (Coleoptera, Carabidae) in immissionsbelasteten Kiefernbeständen des Berliner Grunewaldes. Zool Beitr N F 33: 265-294

4. SZYSZKO J, VERMEULEN H J W, DEN BOER PJ 1996 Survival and reproduction in relation to habitat quality and food availability for Pterostichus oblongopunctatus F. (Carabidae, Col.). Acta Jutl 71: 25-40

5. TENHUMBERG B, TYRE A J, ROITBERG B 2000 Stochastic variation in food availability influences weight and age at maturity. J Theor Biol 202: 257-272 http://dx.doi.org/10.1006/jtbi.1999.1049

6. LINDENMAYER D B, MARGULES C R, BOTKIN D B 2000 Indicators of biodiversity for ecologically sustainable forest management. Conserv Biol 14: 941-950

7. KOIVULA M J 2011 Useful model organisms, indicators, or both? Ground beetles (Coleoptera, Carabidae) reflecting environmental conditions. ZooKeys 100: 287-317.

http://dx.doi.org/10.3897/zookeys.100.1533

8. SKŁODOWSKI J J W 2006 Anthropogenic transformation of ground beetle assemblages (Coleoptera: Carabidae) in Białowieża Forest, Poland: from primeval forests to managed woodlands of various ages. Entomol Fenn 17: 296-314

9. PIZZOLOTTO R, GOBBI M, BRANDMAYR P 2014 Changes in ground beetle assemblages above and below the treeline of the Dolomites after almost 30 years (1980/2009). Ecol Evol 4: 12841294. http://dx.doi.org/10.1002/ece3.927

10. HODECEK J, KURAST,ŠIPOŠ J, DOLNÝ A 2015 Post-industrial areas as successional habitats: Long-term changes of functional diversity in beetle communities. Basic Appl Ecol 16: 629-640. http://dx.doi.org/10.1016/j.baae.2015.06.004

11. BLAKE S, FOSTER G N, EYRE M D, LUFF M L 1994 Effects of habitat type and grassland management practices on the body size distribution of carabid beetles. Pedobiol 38: 502-512

12. CÁRDENAS A M, \& HIDALGO J M 2007 Application of the mean individual biomass (MIB) of ground beetles (Coleoptera, Carabidae) to assess the recovery process of the Guadiamar Green Corridor (southern Iberian Peninsula). Biodivers Conserv 16: 41314146 http://dx.doi.org/10.1007/s10531-007-9211-5

13. SZYSZKO J 1990 Planning of prophylaxis in threatened pine forest biocoenoses based on an analysis of the fauna of epigeic Carabidae. Warsaw Agricultural University Press, Warsaw, p 96

14. SCHWERK A, SZYSZKO J 2008 Patterns of succession and conservation value of post-industrial areas in central Poland based on carabid fauna (Coleoptera: Carabidae). In: Penev L, Erwin T, Assmann $\mathrm{T}$ (eds) Back to the roots and back to the future. Towards a new synthesis between taxonomic, ecological and biogeographical approaches in Carabidology. Pensoft Publishers, Sofia, Moscow, p 469-481 
15. ŠERIĆ JELASKA L,DUMBOVIĆ V, KUČINIĆ M 2011 Carabid beetle diversity and mean individual biomass in beech forests of various ages. ZooKeys 100: 393-405.

http://dx.doi.org./10.3897/zookeys.100.1536

16. SZYSZKO J, VERMEULEN H J W, KLIMASZEWSKI K, ABS M, SCHWERK A 2000 Mean Individual Biomass (MIB) of Carabidae as an indicator of the state of the environment. In: Brandmayr P, Lövei G, Zetto Brandmayr T, Casale A, Vigna Taglianti A $(e d s)$ Natural history and applied ecology of carabid beetles. Pensoft Publishers, Sofia, Moscow, p 288-294

17. BRAUN S D, JONEST H, PERNER J 2004 Shifting average body size during regeneration after pollution -a case study using ground beetle assemblages. Ecol Entomol 29: 543-554

18. LÖVEI G L, MAGURA T 2006 Body size changes in ground beetle assemblages -a reanalysis of Braun et al.(2004)'s data. Ecol Entomol 31: 411-414

19. PARMENTER R R, MACMAHON J A 1987 Early successional patterns of arthropod recolonization on reclaimed strip mines in southwestern Wyoming: the ground-dwelling beetlefauna (Coleoptera). Environ Entomol 16: 168-175

http://dx.doi.org/10.1093/ee/16.1.168

20. PFLUG W(ed) 1998 Braunkohlentagebau und Rekultivierung. Landschaftsökologie - Folgenutzung -Naturschutz. Springer Verlag, Berlin, Heidelberg, New York, p 1068 http://dx.doi.org/10.1007/978-3-642-58846-4

21. SCHWERK A, SZYSZKO J 2011 Model of succession in degraded areas based on carabid beetles (Coleoptera, Carabidae). ZooKeys 100: 319-332. http://zookeys.pensoft.net/articles.php?id=2395

22. SCHWERK A 2014 Changes in carabid beetle fauna (Coleoptera: Carabidae) along successional gradients in post-industrial areas in Central Poland. Eur J Entomol 111: 677-685. doi: 10.14411/ eje.2014.076 http://dx.doi.org/10.14411/eje.2014.076

23. KWIATKOWSKI A 2011 Assemblages of carabid beetles (Coleoptera: Carabidae) in humid forest habitats of different stage of succession in the Puszcza Knyszyńska Forest (northeastern Poland). ZooKeys 100: 447-459. doi: 10.3897/zookeys.100.1539 http://dx.doi.org/10.3897/zookeys.100.1539

24. SCHREINER A 2012 Succession development in forest habitats of the Ruhr valley (Germany) in consideration of ecological aspects and biotope conservation using the example of epigaeic carabid beetles (Coleoptera: Carabidae) as compared to Polish habitats. Dissertation, Warsaw University of Life Sciences -SGGW, Warsaw, p 112

25. FREUDE H, HARDE K-W, LOHSE G A, KLAUSNITZER B 2004 Die Käfer Mitteleuropas. Bd. 2, Adephaga 1, Carabidae (Laufkäfer). 2. (erweiterte) Aufl., Spektrum, Heidelberg/Berlin, p 521

26. SZYSZKO J 1983 Methods of macrofauna investigations. In: Szujecki, A., Szyzsko J, Mazur S, Perliński S (eds) The Process of Forest Soil Macrofauna Formation after Afforestation of Farmland. Warsaw Agricultural University Press, Warsaw, p 10-16

27. TER BRAAK C J F, ŠMILAUER P 2002 CANOCO reference manual and CanoDraw for Windows User's guide: Software for
Canonical Community Ordination (version 4.5). Microcomputer Power, Ithaca, p 499

28. GARBALIŃSKA P, SKŁODOWSKI J 2008 Body size differentiation in selected carabid species inhabiting Puszcza Piska forest stands disturbed by the hurricane. Baltic J Coleopterol 8: 101-114

29. SCHREINER A, SCHWERK A 2011 Standard deviation of carabid size in Western Germany forest succession - a complex picture. Baltic J Coleopterol 11: 25-31

30. SKŁODOWSKI J J W 1995 Soil fertilization and acidification effect on the rate of development of epigeic carabid (Coleoptera, Carabidae) communities in a Scots pine forest plantation. Fol. For est. Pol. ser. A 37: 21-46

31. BAGUETTE M 1993 Habitat selection of carabid beetle in deciduous woodlands of southern Belgium. Pedobiol 37: 365-378

32. GUILLEMAIN M, LOREAU M, DAUFRESNEY T 1997 Relationships between the regional distributions of carabid beetles (Coleoptera, Carabidae) and the abundance of their potential prey. Acta Oecol 18: 465-483 http://dx.doi.org/10.1016/S1146-609X(97)80035-5

33. KOIVULA M, PUNTTILA P, HAILA Y, NIEMELÄJ 1999 Leaf litter and the smale-scale distribution of carabid beetles (Coleoptera, Carabidae) in the boreal forest. Ecography 22: 424-435

34. MAGURA T, TÓTHMÉRÉSZ B, ELEK Z 2003 Diversity and composition of carabids during a forestry cycle. Biodivers Conserv 12: 73-85 http://dx.doi.org/10.1023/A:1021289509500

35. SCHWERKA 2008 Model of the rate of succession of epigeic carabid beetles (Coleoptera: Carabidae) on degraded areas. Instytut Badawczy Leśnictwa, Sękocin Stary,p 71

36. ENGQVIST L 2005: The mistreatment of covariate interaction terms in linear model analyses of behavioural and evolutionary ecology studies. Anim Behav 70: 967-971 http://dx.doi.org/10.1016/j.anbehav.2005.01.016

37. TROPEK R, KADLECT, KARESOVA P, SPITZER L, KOCAREK P, MALENOVSKY I, BANAR P, TUF I H, HEJDA M, KONVICKA M 2010 Spontaneous succession in limestone quarries as an effective restoration tool for endangered arthropods and plants. J Appl Ecol 47: 139-147. http://dx.doi.org/10.1111/j.1365-2664.2009.01746.x

38. DYMITRYSZYN I 2014 The effect of the construction and renovation of a highway bypass in Central Poland on the carabid beetle fauna (Coleoptera: Carabidae). Eur J Entomol 111: 655-662. http://dx.doi.org/10.14411/eje.2014.081

39. SZYSZKO J, SCHWERK A, MALCZYK J 2011 Animals as indicator of carbon sequestration and valuabe landscapes. ZooKeys 100: 565-573. http://dx.doi.org/10.3897/zookeys.100.1547

40. HENDRICKX F, MAELFAIT J-P, VAN WINGERDEN W, SCHWEIGER O, SPEELMANS M, AVIRON I, AUGENSTEIN I, BILLETER R, BAILEY D, BUKACEK R, BUREL F, DIEKÖTTER T, DIRKSEN J, HERZOG F, LIRA J, ROUBALOVA M, VANDOMME V, BUGTER R 2007 How landscape structure, land-use intensity and habitat diversity affect components of total arthropod diversity in agricultural landscapes. J Appl Ecol 44:340351 
Appendix 1: Information on individual samples with respect to study year(s), age of site, number of carabid individuals (n), mean individual biomass of Carabidae (MIB), standard deviation (SD), and coefficient of variation (CV). Age of site refers to each first year (study sites at Betchatów) and to the year 2007 (study sites in Puszcza Knyszyńska), respectively. BE-Betchatów, PK-Puszcza Knyszyńska, RV-Ruhr valley.

\begin{tabular}{|c|c|c|c|c|c|c|}
\hline $\begin{array}{l}\text { Study } \\
\text { site }\end{array}$ & $\begin{array}{l}\text { Study } \\
\text { year(s) }\end{array}$ & $\begin{array}{l}\text { Age of } \\
\text { site }\end{array}$ & $\mathrm{n}$ & MIB & SD & $\mathrm{CV}$ \\
\hline BE1 & $2004 / 05$ & 8 & 621 & 59.18 & 27.40 & 0.46 \\
\hline BE1 & $2006 / 07$ & 10 & 170 & 65.79 & 35.57 & 0.54 \\
\hline BE1 & $2008 / 09$ & 12 & 59 & 83.98 & 122.67 & 1.46 \\
\hline BE1 & $2010 / 11$ & 14 & 120 & 146.49 & 96.07 & 0.66 \\
\hline BE2 & $2004 / 05$ & 10 & 281 & 60.84 & 22.88 & 0.38 \\
\hline BE2 & $2006 / 07$ & 12 & 99 & 50.78 & 31.04 & 0.61 \\
\hline BE2 & $2008 / 09$ & 14 & 59 & 69.53 & 110.63 & 1.59 \\
\hline BE2 & 2010/11 & 16 & 58 & 98.33 & 121.91 & 1.24 \\
\hline BE3 & $2004 / 05$ & 12 & 174 & 47.91 & 95.26 & 1.99 \\
\hline BE3 & $2006 / 07$ & 14 & 63 & 82.81 & 144.87 & 1.75 \\
\hline BE3 & $2008 / 09$ & 16 & 60 & 87.12 & 142.52 & 1.64 \\
\hline BE3 & 2010/11 & 18 & 66 & 111.44 & 90.49 & 0.81 \\
\hline BE4 & $2004 / 05$ & 3 & 165 & 42.22 & 11.37 & 0.27 \\
\hline BE4 & $2006 / 07$ & 5 & 245 & 43.19 & 17.70 & 0.41 \\
\hline BE4 & $2008 / 09$ & 7 & 348 & 52.28 & 33.24 & 0.64 \\
\hline BE4 & $2010 / 11$ & 9 & 103 & 142.69 & 88.38 & 0.62 \\
\hline BE5 & $2004 / 05$ & 10 & 50 & 50.62 & 27.85 & 0.55 \\
\hline BE5 & $2006 / 07$ & 12 & 59 & 48.78 & 24.37 & 0.50 \\
\hline BE5 & $2008 / 09$ & 14 & 37 & 55.05 & 41.43 & 0.75 \\
\hline BE5 & 2010/11 & 16 & 42 & 100.50 & 81.68 & 0.81 \\
\hline BE6 & $2004 / 05$ & 14 & 98 & 214.62 & 200.99 & 0.94 \\
\hline BE6 & $2006 / 07$ & 16 & 29 & 147.66 & 162.79 & 1.10 \\
\hline BE6 & $2008 / 09$ & 18 & 83 & 202.70 & 165.26 & 0.82 \\
\hline BE6 & 2010/11 & 20 & 97 & 256.97 & 184.63 & 0.72 \\
\hline BE7 & $2004 / 05$ & 21 & 117 & 222.84 & 187.20 & 0.84 \\
\hline BE7 & $2006 / 07$ & 23 & 118 & 131.84 & 146.26 & 1.11 \\
\hline BE7 & $2008 / 09$ & 25 & 88 & 160.36 & 155.65 & 0.97 \\
\hline BE7 & 2010/11 & 27 & 41 & 96.66 & 141.07 & 1.46 \\
\hline PK1 & 2006-08 & 3 & 259 & 118.22 & 222.20 & 1.88 \\
\hline PK2 & 2006-08 & 3 & 168 & 95.19 & 152.99 & 1.61 \\
\hline PK3 & 2006-08 & 3 & 148 & 324.32 & 534.07 & 1.65 \\
\hline PK4 & 2006-08 & 4 & 129 & 274.64 & 452.98 & 1.65 \\
\hline PK5 & 2006-08 & 7 & 81 & 133.43 & 325.33 & 2.44 \\
\hline PK6 & 2006-08 & 8 & 61 & 115.43 & 227.14 & 1.97 \\
\hline PK7 & 2006-08 & 13 & 451 & 70.32 & 195.44 & 2.78 \\
\hline PK8 & 2006-08 & 22 & 281 & 271.13 & 439.68 & 1.62 \\
\hline PK9 & 2006-08 & 26 & 159 & 121.67 & 212.80 & 1.75 \\
\hline
\end{tabular}

\begin{tabular}{|c|c|c|c|c|c|c|}
\hline PK10 & 2006-08 & 28 & 116 & 328.44 & 604.75 & 1.84 \\
\hline$\measuredangle 11$ & 2006-08 & 29 & 165 & 146.63 & 303.98 & 2.07 \\
\hline PK12 & 2006-08 & 46 & 310 & 163.51 & 324.14 & 1.98 \\
\hline PK13 & 2006-08 & 46 & 326 & 165.27 & 253.86 & 1.54 \\
\hline PK14 & 2006-08 & 68 & 554 & 274.84 & 301.20 & 1.10 \\
\hline PK15 & 2006-08 & 73 & 272 & 242.83 & 304.38 & 1.25 \\
\hline PK16 & 2006-08 & 78 & 442 & 227.86 & 422.55 & 1.85 \\
\hline PK17 & 2006-08 & 81 & 297 & 112.59 & 92.45 & 0.82 \\
\hline PK18 & 2006-08 & 83 & 413 & 179.32 & 184.21 & 1.03 \\
\hline PK19 & 2006-08 & 91 & 549 & 298.01 & 333.85 & 1.12 \\
\hline PK20 & 2006-08 & 93 & 222 & 260.60 & 498.18 & 1.91 \\
\hline PK21 & 2006-08 & 93 & 1353 & 206.82 & 212.86 & 1.03 \\
\hline PK22 & 2006-08 & 101 & 730 & 217.42 & 290.94 & 1.34 \\
\hline PK23 & 2006-08 & 103 & 1206 & 206.58 & 275.67 & 1.33 \\
\hline PK24 & 2006-08 & 127 & 211 & 95.06 & 294.37 & 3.10 \\
\hline RV1 & 2009 & 1 & 744 & 156.88 & 344.55 & 2.20 \\
\hline RV1 & 2010 & 2 & 376 & 178.23 & 334.75 & 1.88 \\
\hline RV2 & 2009 & 1 & 29 & 512.40 & 298.98 & 0.58 \\
\hline RV2 & 2010 & 2 & 206 & 283.02 & 304.81 & 1.08 \\
\hline RV3 & 2009 & 3 & 163 & 265.18 & 283.42 & 1.07 \\
\hline RV3 & 2010 & 4 & 05 & 242.03 & 261.03 & 1.08 \\
\hline RV4 & 2009 & 4 & 139 & 402.37 & 264.62 & 0.66 \\
\hline RV4 & 2010 & 5 & 42 & 372.83 & 302.43 & 0.81 \\
\hline RV5 & 2009 & 13 & 125 & 428.34 & 254.89 & 0.60 \\
\hline RV5 & 2010 & 14 & 78 & 241.12 & 244.61 & 1.01 \\
\hline RV6 & 2009 & 20 & 866 & 317.90 & 339.71 & 1.07 \\
\hline $\mathrm{R}$ & 010 & 1 & 589 & 269.24 & 279.22 & 1.04 \\
\hline RV7 & 2009 & 26 & 252 & 697.41 & 375.52 & 0.54 \\
\hline RV7 & 2010 & 27 & 292 & 788.10 & 421.09 & 0.53 \\
\hline RV8 & 2009 & 28 & 699 & 666.67 & 274.78 & 0.41 \\
\hline RV8 & 2010 & 29 & 494 & 663.55 & 230.55 & 0.35 \\
\hline RV9 & 2009 & 52 & 277 & 3 & 2 & 0 \\
\hline RV9 & 2010 & ת & 353 & 776 & 267 & 0.34 \\
\hline RV10 & 2009 & 78 & 477 & 622.06 & 297.77 & 0.48 \\
\hline RV10 & 2010 & 79 & 373 & 721.09 & 294.26 & 0.41 \\
\hline RV11 & 2009 & 14 & 586 & 654.30 & 293.36 & 0.45 \\
\hline RV11 & 2010 & 147 & 862 & 683.01 & 254.29 & 0.37 \\
\hline RV12 & 2009 & 146 & 442 & 700.24 & 287.68 & 0.41 \\
\hline RV12 & 2010 & 147 & 476 & 737.95 & 281.58 & 0.38 \\
\hline RV13 & 2009 & 152 & 273 & 426.19 & 312.55 & 0.73 \\
\hline RV13 & 2010 & 153 & 321 & 648.13 & 230.28 & 0.36 \\
\hline RV14 & 2009 & 165 & 264 & 733.63 & 323.09 & 0.44 \\
\hline RV14 & 2010 & 166 & 130 & 722.70 & 241.34 & 0.33 \\
\hline
\end{tabular}

